\title{
Day 100 Absolute Monocyte/Lymphocyte Prognostic Score and Survival Post Autologous Peripheral Blood Hematopoietic Stem Cell Transplantation in Diffuse Large B-Cell Lymphoma*
}

\author{
Ana I. Velazquez, David J. Inwards, Stephen M. Ansell, Ivana N. Micallef, Patrick B. Johnston, \\ William J. Hogan, Svetomir N. Markovic, Luis F. Porrata\#
}

Division of Hematology, Department of Internal Medicine, Mayo Clinic, Rochester, USA.

Email: "\#prrata.luis@mayo.edu

Received September $4^{\text {th }}, 2013$; revised October $2^{\text {nd }}, 2013$; accepted October $9^{\text {th }}, 2013$

Copyright (C) 2013 Ana I. Velazquez et al. This is an open access article distributed under the Creative Commons Attribution License, which permits unrestricted use, distribution, and reproduction in any medium, provided the original work is properly cited.

\begin{abstract}
Day 100 prognostic factors post-autologous peripheral blood hematopoietic stem cell transplantation (APBHSCT) to predict clinical outcomes in diffuse large B-cell lymphoma (DLBCL) patients have not been studied. Thus, we retrospectively examined if day 100 absolute monocyte/lymphocyte prognostic score (AMLPS-100) affects clinical outcomes by landmark analysis from day 100 post-APBHSCT in DLBCL. Only DLBCL patients in complete remission at day 100 post-APBHSCT were evaluated. From 2000 to 2007, 134 consecutive DLBCL patients are qualified for the study. Patients with a day 100 absolute monocyte count (AMC-100) $\geq 630$ cells $/ \mu \mathrm{L}$ and day 100 absolute lymphocyte count $($ ALC-100) $\leq 1000$ cells $/ \mu \mathrm{L}$ experienced inferior overall survival (OS) and progression free survival (PFS). On multivariate analysis, the AMC-100 and ALC-100 remained independent predictors of OS and PFS. Combining both values into the AMLPS-100, the 5-year OS rates for low, intermediate, and high AMLPS-100 risk groups were 94\% (95\% CI, $83.0 \%-98.1 \%), 70 \%(95 \%$ CI, 58.6\% - 80.1\%), and 13\% (95\% CI, 3.4\% - 40.5\%), respectively; and the 5-year PFS rates were $87 \%$ (95\% CI, 74.0\% - 94.1\%), 68\% (95\% CI, 56.0\% - 77.8\%), and $13 \%$ (95\% CI, 3.4\% $40.5 \%$ ), respectively. The AMLPS-100 is a simple biomarker score that can stratify clinical outcomes from day 100 post-APBHSCT in DLBCL patients.
\end{abstract}

Keywords: Monocyte/Lymphocyte Prognostic Score; Diffuse Large B-Cell Lymphoma; Survival; Autologous Peripheral Blood Hematopoietic Stem Cell Transplantation

\section{Introduction}

Day 100 visit after stem cell transplantation is the current standard first follow-up visit to assess treatment response. Day 100 absolute lymphocyte count (ALC-100) [1], day 100 absolute monocyte count (AMC-100) [1], day 100 platelet count [2], graft versus host disease [3], and day 100 full donor chimerism [4] are day 100 prognostic factors related to clinical outcomes in allogeneic stem cell transplantation. In autologous peripheral blood hemato-

\footnotetext{
*Financial Disclosure Statement: This publication was supported in part by Mayo CTSA Grant Number UL1TR000135 from the National Center for Advancing Translational Sciences. Its contents are solely the responsibility of the authors and do not necessarily represent the official view of NIH.

Conflict of Interest: The authors declare no conflict of interest.

${ }^{\#}$ Corresponding author.
}

poietic stem cell transplantation (APBHSCT), multiple myeloma documented minimal residual disease at day 100 was associated with inferior survival. Nevertheless, prognostic factors to assess prognosis for diffuse large B-cell lymphoma (DLBCL) patients achieving a complete remission at day 100 post-APBHSCT have not been evaluated. We previously reported that the absolute lymphocyte count (ALC) and absolute monocyte count (AMC) at diagnosis are independent predictors of overall survival (OS) and progression-free survival (PFS) in DLBCL [5]. The combination of both biomarkers into the AMC/ ALC prognostic score (AMLPS) stratifies patients into three risk groups: low-(AMC $<630$ cells $/ \mu \mathrm{L}$ and ALC $>1000$ cells $/ \mu \mathrm{L})$, intermediate $-(\mathrm{AMC} \geq 630 \mathrm{cells} / \mu \mathrm{L}$ or $\mathrm{ALC} \leq 1000$ cells $/ \mu \mathrm{L})$ and high-risk (AMC $\geq 630$ cells/ 
$\mu \mathrm{L}$ and ALC $\leq 1000$ cells $/ \mu \mathrm{L}$ ) [5]. The AMLPS has been recently validated in several independent studies [6,7] confirming its utility as an assessment tool of prognosis in DLBCL. Post-transplant immunologic reconstitution, particularly ALC recovery (ALC $\geq 500$ cells $/ \mu \mathrm{L}$ ) at day 15 , has also been associated with prolonged PFS and OS in multiple hematological malignancies [8-19] and solid tumors [20-22].

However, recent reports suggest that the survival benefit obtained from early lymphocyte recovery poststem cell transplant in DLBCL patients could be lost with long-term follow-up [10]. Therefore, the aim of this study was to evaluate if day 100 AMLPS (AMLPS-100) affects survival for DLBCL patients in complete remission at day 100 post-APBHSCT. The value of AMLPS100 was also evaluated as a tool to identify high-risk patients for post-APBHSCT relapse that is simple and could be easily implemented in clinical practice.

\section{Materials and Methods}

\subsection{Patient Population}

DLBCL patients achieving complete remission at day 100 post-APBHSCT at Mayo Clinic, Rochester, MN between 2000 and 2007 were considered for this study. Patients transplanted with bone marrow or combined bone marrow and peripheral blood stem cells and patients with evidence of relapse or progression at day 100 post-APBHSCT were excluded. A total of 134 consecutive DLBCL patients in complete remission at day 100 post-APBHSCT qualified for the study. No patient refused authorization to use their medical records for research and none were lost to follow-up. Approval for the retrospective review of these patients' records was obtained from the Mayo Clinic Institutional Review Board and the research was conducted in accordance with US federal regulations and the Declaration of Helsinki.

\subsection{End Points}

The primary end point of the study was to assess the impact of AMLPS- 100 on OS and PFS by landmark analysis from day 100 in DLBCL patients treated with APBHSCT. The AMC-100, ALC-100, and AMLPS-100 were obtained from a standard day 100 complete blood cell count (CBC). The secondary end point was to evaluate if the AMLPS-100 could stratify DLBCL patients into low-, intermediate- and high-risk groups for OS and PFS post-APBHSCT.

\subsection{Conditioning Regimen}

All patients received carmustine (BCNU) $300 \mathrm{mg} / \mathrm{m}^{2}$ on day-6; etoposide $100 \mathrm{mg} / \mathrm{m}^{2}$ twice a day on days-5, $-4,-3$, and -2 ; cytarabine $100 \mathrm{mg} / \mathrm{m}^{2}$ twice a day on days-5, -4 , $-3,-2$; and melphalan $140 \mathrm{mg} / \mathrm{m}^{2}$ on day-1 (BEAM).

\subsection{Prognostic Factors}

Prognostic factors evaluated include: age at day 100 (Age-100), ALC-100, AMC-100, absolute neutrophil count at day 100 (ANC-100), gender, International Prognostic Index (IPI) at diagnosis, infused CD34+ cell dose, lactate dehydrogenase at day 100 (LDH-100), hemoglobin at day 100 (Hgb-100), platelets at day 100 (Plts$100)$, day 15 absolute lymphocyte count post-APBHSCT (ALC-15), and white blood cell count at day 100 (WBC100).

\subsection{Response and Survival}

Response criteria were based on the guidelines from the International Harmonization Project for Malignant Lymphoma [23]. OS was measured from day 100 to the date of death, or last follow-up. PFS was defined as the time from day 100 to the time of progression, relapse, death, or last follow-up, whichever occurred first.

\subsection{Statistical Analysis}

OS and PFS were analyzed using the approach of Kaplan-Meier [24]. Differences between the survival curves were tested for statistical significance using the 2-tailed log-rank test. The Cox proportional hazard model was used for the univariate and multivariate analysis to evaluate the impact of the variables listed under the prognostic factors section for OS and PFS times [25]. The choice of the cut-off values for ALC-100 and AMC-100 was based on our previous AMLPS publication [5]. $\chi^{2}$ analysis was used to determine relationships between categorical variables. The Wilcoxon-rank test was used to determine associations between continuous variables and categories, and Spearman correlation coefficients were used to evaluate associations for continuous variables. All twosided $\mathrm{p}$-values $<0.05$ were determined to be statistically significant.

\section{Results}

\subsection{Patients' Characteristics}

For this cohort of 134 DLBCL patients, the median age at day 100 post-APBHSCT was 57.5 years (range: 23 77 years). Sixty-three percent of the patients were males, while $37 \%$ were females. The distribution of the patients' baseline characteristics at day 100 is included in Table 1. The median follow-up period from day 100 postAPBHSCT for the cohort was 5.5 years (range: $0.1-12.7$ years) and for living patients $(\mathrm{N}=93)$ was 6.9 years (range: 2.5 - 12.7 years). Twenty-seven patients died 
Table 1. Baseline patients' characteristics at day $100(\mathrm{~N}=134)$.

\begin{tabular}{|c|c|c|c|}
\hline Characteristics & N (\%) & Median & Range \\
\hline \multicolumn{4}{|l|}{ Gender } \\
\hline Male & $84(63)$ & & \\
\hline Female & $50(37)$ & & \\
\hline Age-100, years & $134(100)$ & 57.5 & $(23-77)$ \\
\hline $\mathrm{CD} 34+$ & $134(100)$ & 4.43 & $(2.05-14.85)$ \\
\hline ALC- $15, \times 10^{9} / \mathrm{L}$ & $134(100)$ & 0.575 & $(0.02-2.4)$ \\
\hline AMC $-100, \times 10^{9} / \mathrm{L}$ & $134(100)$ & 0.49 & $(0.08-1.8)$ \\
\hline ALC- $100, \times 10^{9} / \mathrm{L}$ & $134(100)$ & 1.045 & $(0.17-5.6)$ \\
\hline ANC- $100, \times 10^{9} / \mathrm{L}$ & $134(100)$ & 2.455 & $(0.22-7.8)$ \\
\hline WBC $-100, \times 10^{9} / \mathrm{L}$ & $134(100)$ & 4.4 & $(1.1-10.9)$ \\
\hline $\mathrm{Hgb}-100, \mathrm{~g} / \mathrm{L}$ & $134(100)$ & 11.75 & $(7.5-15.8)$ \\
\hline Plts- $100, \times 10^{9} / \mathrm{L}$ & $134(100)$ & 152.5 & $(17-403)$ \\
\hline LDH-100, U/L & $134(100)$ & 167.5 & $(111-383)$ \\
\hline \multicolumn{4}{|l|}{ IPI } \\
\hline 0 & $13(9.7)$ & & \\
\hline 1 & $44(32.8)$ & & \\
\hline 2 & $52(38.8)$ & & \\
\hline 3 & $21(15.7)$ & & \\
\hline 4 & $4(3)$ & & \\
\hline \multicolumn{4}{|l|}{ AMLPS-100 } \\
\hline Low risk & $50(37.3)$ & & \\
\hline Intermediate risk & $69(51.5)$ & & \\
\hline High risk & $15(11.2)$ & & \\
\hline
\end{tabular}

Abbreviations: $\mathrm{ALC}=$ absolute lymphocyte count; $\mathrm{AMC}=$ absolute monocyte count; $\mathrm{ANC}=$ absolute neutrophil count; $\mathrm{WBC}=$ white blood cell count; $\mathrm{Hgb}=$ hemoglobin; Plts = platelets; LDH = lactate dehydrogenase; IPI = International Prognostic Index; AMLPS = AMC/ALC Prognostic Score.

secondary to relapsed DLBCL. Fourteen patients died of causes not related to DLBCL: 3 patients died of acute respiratory distress syndrome; 3 patients of myelodysplastic syndrome; 2 patients of acute myelogenous leukemia; 2 patients of myocardial infarction; 2 patients of suicide; 1 patient of a motor vehicle accident; and 1 patient of sepsis.

\subsection{AMC-100, ALC-100, and Survival}

To determine if AMC-100 and ALC-100 affect survival, we evaluated by univariate analysis both variables as continuous predictors of OS and PFS. As continuous variables both, AMC-100 and ALC-100, predicted OS $[$ Hazard ratio $(\mathrm{HR})=7.16, \mathrm{p}<0.0001$ and $\mathrm{HR}=0.42, \mathrm{p}$ $<0.009$, respectively] and PFS $[\mathrm{HR}=5.06, \mathrm{p}<0.0005$ and $\mathrm{HR}=0.44, \mathrm{p}<0.005$, respectively] (Table 2). AMC-100 and ALC-100 were dichotomized using cut- off values previously published [AMC: $<630$ cells $/ \mu \mathrm{L}$ vs. $\geq 630$ cells $/ \mu \mathrm{L} ;$ ALC: $\leq 1000$ cells $/ \mu \mathrm{L}$ vs. $>1000$ cells/ $\mu \mathrm{L}$ ] [5]. An elevated AMC-100, defined as $\geq 630$ cells $/ \mu \mathrm{L}$, was associated with inferior OS and PFS on univariate analysis [OS: $\mathrm{HR}=2.46,(95 \% \mathrm{CI}, 1.32$ 4.55), $\mathrm{p}<0.005$; PFS:HR = 1.75, (95\% CI, 0.99 - 3.03), $\mathrm{p}<0.05]$. An ALC-100 $\leq 1000$ cells $/ \mu \mathrm{L}$ was associated with inferior OS and PFS [OS: HR = 4.85, (95\% CI, 2.46 - 10.43), p < 0.0001; PFS: HR = 3.41, (95\% CI, 1.93 $6.25), \mathrm{p}<0.0001]$. Figures 1(a) and (b) show superior OS and PFS based on AMC-100 < 630 cells $/ \mu \mathrm{L}$ versus AMC $-100 \geq 630$ cells $/ \mu \mathrm{L}$ [median OS $=$ not reached vs. 7.3 years, 5-year OS rates of $80 \%$, (95\% CI 70.4\% $87.1 \%)$ vs. $55 \%$, (95\% CI, 40.1\% - 69.9\%), p < 0.007 , respectively; and median PFS $=10.9$ years vs. 7.3 years, 5 -year PFS rates of $75 \%$, (95\% CI $64.7 \%-82.6 \%)$, vs. $55 \%$, (95\% CI, 40.1\% - 69.9\%), p < 0.04, respectively]. Figures 1(c) and (d) show superior OS and PFS based on 
Day 100 Absolute Monocyte/Lymphocyte Prognostic Score and Survival Post Autologous Peripheral Blood Hematopoietic Stem Cell Transplantation in Diffuse Large B-Cell Lymphoma

Table 2. Univariate analysis for overall survival and progression-free survival.

\begin{tabular}{|c|c|c|c|c|}
\hline \multirow{2}{*}{ Prognostic factors } & \multicolumn{2}{|c|}{ Overall survival } & \multicolumn{2}{|c|}{ Progression-free survival } \\
\hline & HR $(95 \%$ CI) & p-value & HR $(95 \%$ CI) & p-value \\
\hline Gender & & $<0.0227$ & & \\
\hline Male & $2.19(1.11-4.70)$ & & $1.76(0.99-3.32)$ & 0.0552 \\
\hline Female & $0.46(0.21-0.90)$ & & $0.57(0.30-1.01)$ & \\
\hline Age-100, years (continuous variable) & $1.05(1.02-1.08)$ & $<0.0003$ & $1.04(1.02-1.07)$ & $<0.0002$ \\
\hline Age at day $100, \geq 60$ years & $2.59(1.38-5.08)$ & $<0.0029$ & $2.54(1.46-4.56)$ & $<0.0009$ \\
\hline CD34+ & $0.84(0.69-0.99)$ & $<0.0404$ & $0.87(0.74-1.01)$ & 0.0631 \\
\hline IPI, $\geq 2$ & $1.60(0.85-3.13)$ & 0.1508 & $1.62(0.92-2.93)$ & 0.0940 \\
\hline ALC- $15, \times 10^{9} / \mathrm{L}$ & $0.20(0.07-0.52)$ & $<0.0005$ & $0.37(0.15-0.80)$ & $<0.0104$ \\
\hline AMC $-100, \times 10^{9} / \mathrm{L}$ (continuous variable) & $7.11(2.86-16.08)$ & $<0.0001$ & $5.06(2.12-11.00)$ & $<0.0005$ \\
\hline $\mathrm{AMC}-100 \geq 630 / \mu \mathrm{L}$ & $2.46(1.32-4.55)$ & $<0.0048$ & $1.75(0.99-3.03)$ & 0.0533 \\
\hline ALC-100, $\times 10^{9} / \mathrm{L}$ (continuous variable) & $0.42(0.20-0.82)$ & $<0.0094$ & $0.44(0.22-0.79)$ & $<0.0049$ \\
\hline ALC $-100 \leq 1000 / \mu \mathrm{L}$ & $4.85(2.46-10.43)$ & $<0.0001$ & $3.41(1.93-6.25)$ & $<0.0001$ \\
\hline ANC $-100 \times 10^{9} / \mathrm{L}$ & $1.13(0.91-1.36)$ & 0.2635 & $1.11(0.92-1.32)$ & 0.2814 \\
\hline WBC- $100, \times 10^{9} / \mathrm{L}$ & $1.05(0.89-1.22)$ & 0.5687 & $1.04(0.89-1.19)$ & 0.6376 \\
\hline Hgb-100, g/L & $0.71(0.59-0.85)$ & $<0.0002$ & $0.78(0.67-0.92)$ & $<0.0026$ \\
\hline Plts- $100, \times 10^{9} / \mathrm{L}$ & $1.00(0.994-1.001)$ & 0.2590 & $0.99(0.99-1.00)$ & 0.6292 \\
\hline LDH-100, U/L & $1.00(1.00-1.01)$ & 0.2274 & $1.00(0.99-1.01)$ & 0.3386 \\
\hline
\end{tabular}

Abbreviations: IPI = International Prognostic Index; ALC = absolute lymphocyte count; AMC = absolute monocyte count; ANC = absolute neutrophil count $\mathrm{WBC}=$ white blood cell count; $\mathrm{Hgb}=$ hemoglobin; $\mathrm{Plts}=$ platelets; $\mathrm{LDH}=$ lactate dehydrogenase.

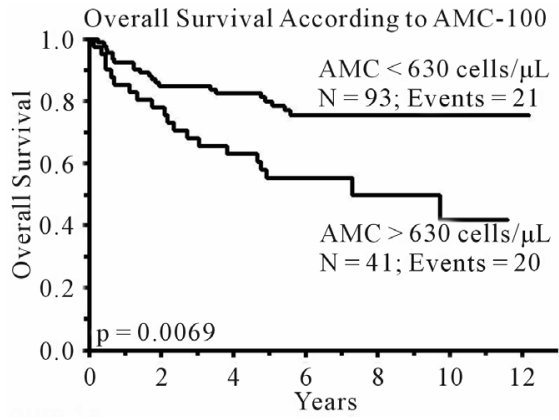

(a)



(c)

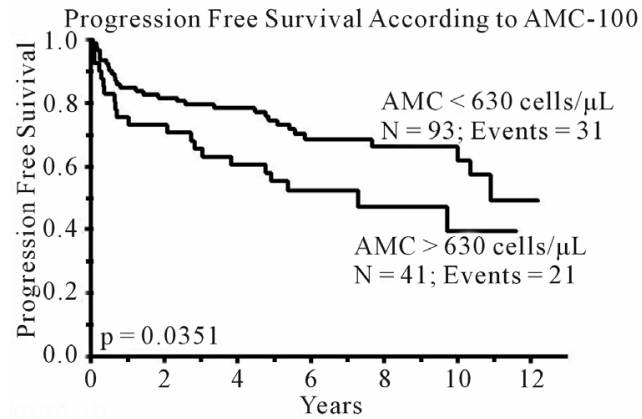

(b)

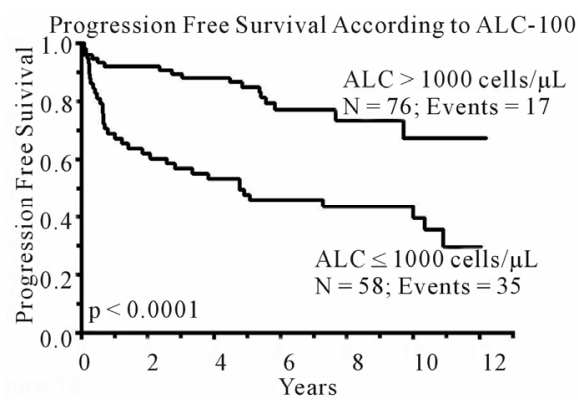

(d)

Figure 1. (a) Kaplan-Meier estimates of overall survival from day 100 post-APBHSCT based on day 100 absolute monocyte count (AMC-100); (b) Kaplan-Meier estimates of progression-free survival from day 100 post-APBHSCT based on day 100 absolute monocyte count (AMC-100); (c) Kaplan-Meier estimates of overall survival from day 100 post-APBHSCT based on day 100 absolute lymphocyte count (ALC-100); and (d) Kaplan-Meier estimates of progression-free survival from day 100 post-APBHSCT based on day 100 absolute lymphocyte count (ALC-100). 
ALC-100 > 1000 cells $/ \mu \mathrm{L}$ versus ALC-100 $\leq 1000$ cells/ $\mu \mathrm{L}[$ median OS $=$ not reached vs. 5.1 years, 5-year OS rates of $89 \%,(95 \% \mathrm{CI}, 80.2 \%-94.6 \%)$, vs. $49 \%,(95 \%$ CI, $36.1 \%-61.7 \%), p<0.0001$, respectively; and median PFS = not reached vs. 4.8 years, 5-year PFS rates of $85 \%$, $(95 \% \mathrm{CI}=74.9 \%$ - 91.5\%) vs. $46 \%$, (95\% CI, $33.6 \%-58.9 \%), \mathrm{p}<0.0001$, respectively].

\subsection{Univariate and Multivariate Analysis}

Gender, age-100 (continuous and dichotomized), CD34+, IPI, ALC-15, ALC-100 (continuous and dichotomized), AMC-100 (continuous and dichotomized), and Hgb-100 were identified as predictors for OS and PFS in the univariate analysis (Table 2). In the multivariate analysis, CD34+ and ALC-15 continue to be independent predictors of OS and PFS post-APBHSCT; age dichotomized as $<$ or $\geq 60$ years was associated with PFS. Both AMC $-100 \geq 630$ cells $/ \mu \mathrm{L}$ and ALC $-100 \leq 1000$ cells $/ \mu \mathrm{L}$ remained as independent predictors of OS after adjusting for several variables on multivariate analysis, with hazard ratios of 3.83 and 5.46 respectively $(\mathrm{p}<0.0002$; $\mathrm{p}<$ $0.0001)$; both day 100 variables were independent predictors of PFS (Table 3).

\subsection{Day 100 AMLPS (AMLPS-100)}

By univariate and multivariate analysis, the ALC-100 and AMC-100 were independent predictors for OS and PFS post-APBHSCT. Thus, we combinedALC-100 and AMC-100 into day $100 \mathrm{AMC} / \mathrm{ALC}$ prognostic score (AMLPS-100), using the same cut-off values from our previous publication of the AMLPS at diagnosis in DLBCL [5], to develop a simple scoring system that can be used to stratify by risk patients with DLBCL that are in complete disease remission at day 100 post-APBHSCT.
According to the AMLPS-100, 37.3\% $(\mathrm{N}=50)$ of the patients were considered low risk (AMC $<630$ cells $/ \mu \mathrm{L}$ and $\mathrm{ALC}>1000$ cells $/ \mu \mathrm{L}), 51.5 \%(\mathrm{~N}=69)$ intermediate risk $(\mathrm{AMC} \geq 630$ cells $/ \mu \mathrm{L}$ or $\mathrm{ALC} \leq 1000$ cells $/ \mu \mathrm{L})$, and $11.2 \%(\mathrm{~N}=15)$ high risk (AMC $\geq 630$ cells $/ \mu L$ and ALC $\leq 1000$ cells $/ \mu \mathrm{L}$ ) (Table 4). Among the groups significant differences were seen in ALC-100, AMC-100, ANC-100, and $\mathrm{HgB}-100$. Patients with a low-risk AMLPS-100 experienced significantly superior OS and PFS compared to the other groups, with a 5-year OS rate of $94 \%(95 \% \mathrm{CI}$, 83.0\% - 98.1\%); median not reached; $\mathrm{p}<0.0001$ and a 5-year PFS rate of $87 \%$ (95\% CI, 74.0\% - 94.1\%); median not reached; $\mathrm{p}<0.0001$ (Figures 2(a) and (b)). The estimated 5-year OS among intermediate-risk patients was 70\% (95\% CI, 58.6\% - 80.1\%); median not reached (Figure 2(a)) and the 5-year PFS was 68\% (95\% CI, $56.0 \%-77.8 \%$ ) with a median PFS of 10.9 years (Figure 2(b)). The AMLPS-100 identified a group of high-risk patients with median OS of 2.18 years and an estimated 5-year OS of 13\% (95\% CI, 3.4\% - 40.5\%) (Figure 2(a)). Similarly, the median PFS for high-risk patients was 1 year with an estimated 5-year PFS rate of $13 \%(95 \% \mathrm{CI}$, $3.4 \%-40.5 \%$ ) (Figure 2(b)).

\section{Discussion}

Currently, there are no studies available to advise DLBCL patients in complete remission at day 100 postAPBHSCT of their long-term prognosis starting at day 100 post-APBHSCT. We previously published the AMLPS at diagnosis for DLBCL stratifies patients into three risk groups in regard to clinical outcomes. This AMLPS has been validated as an independent prognostic indicator in DLBCL patients by other independent groups $[6,7]$. Hence, we sought to evaluate if the AMLPS-

Table 3. Multivariate analysis for overall survival and progression-free survival.



Abbreviations: IPI = International Prognostic Index; ALC = absolute lymphocyte count; AMC = absolute monocyte count; Hgb = hemoglobin. 
Day 100 Absolute Monocyte/Lymphocyte Prognostic Score and Survival Post Autologous Peripheral Blood Hematopoietic Stem Cell Transplantation in Diffuse Large B-Cell Lymphoma

Table 4. Baseline patients' characteristics based on AMLPS-100.

\begin{tabular}{|c|c|c|c|c|}
\hline Characteristics & Low Risk (N = 50) & Intermediate Risk $(\mathrm{N}=69)$ & High Risk (N = 15) & p-value \\
\hline \multicolumn{5}{|l|}{ Gender } \\
\hline Male & $30(60 \%)$ & $43(62 \%)$ & $11(73 \%)$ & \multirow[t]{2}{*}{0.6424} \\
\hline Female & $20(40 \%)$ & $26(38 \%)$ & $4(27 \%)$ & \\
\hline Age-100, years & $58.5(24-75)$ & $56(23-76)$ & $62(41-77)$ & 0.2190 \\
\hline CD34+ & $4.47(2.05-8.23)$ & $4.41(2.11-14.85)$ & $3.82(2.22-9.95)$ & 0.9875 \\
\hline ALC- $15, \times 10^{9} / \mathrm{L}$ & $0.68(0.03-2.4)$ & $0.56(0.02-1.89)$ & $0.47(0.14-1.79)$ & 0.2133 \\
\hline AMC- $100, \times 10^{9} / \mathrm{L}$ & $0.43(0.08-0.61)$ & $0.50(0.08-1.80)$ & $1.00(0.63-1.65)$ & $<0.0001$ \\
\hline ALC- $100, \times 10^{9} / \mathrm{L}$ & $1.26(1.01-3.06)$ & $0.91(0.17-5.60)$ & $0.71(0.20-0.92)$ & $<0.0001$ \\
\hline ANC- $100, \times 10^{9} / \mathrm{L}$ & $2.30(0.27-5.25)$ & $2.59(0.28-7.80)$ & $3.27(0.22-6.83)$ & $<0.0462$ \\
\hline WBC- $100, \times 10^{9} / \mathrm{L}$ & $4.4(1.9-9.3)$ & $4(1.1-10.8)$ & $4.6(1.9-10.9)$ & 0.3008 \\
\hline Hemoglobin at day $100, \mathrm{~g} / \mathrm{L}$ & $12.5(7.9-15.8)$ & $11.3(7.5-14.7)$ & $11.8(8.1-13.8)$ & $<0.0027$ \\
\hline Platelets at day $100, \times 10^{9} / \mathrm{L}$ & $164(23-373)$ & $139(17-403)$ & $195(36-299)$ & 0.0939 \\
\hline LDH-100, U/L & $170(117-286)$ & $166(111-383)$ & $162(130-255)$ & 0.9301 \\
\hline \multicolumn{5}{|l|}{ IPI } \\
\hline 0 & $4(8 \%)$ & $9(13 \%)$ & $0(0 \%)$ & \multirow{5}{*}{0.2883} \\
\hline 1 & $16(32 \%)$ & $26(36 \%)$ & $3(20 \%)$ & \\
\hline 2 & $23(46 \%)$ & $22(32 \%)$ & 7 (47\%) & \\
\hline 3 & $6(12 \%)$ & $10(15 \%)$ & $5(33 \%)$ & \\
\hline 4 & $1(2 \%)$ & $3(4 \%)$ & $0(0 \%)$ & \\
\hline
\end{tabular}

Abbreviations: $\mathrm{ALC}=$ absolute lymphocyte count; $\mathrm{AMC}=$ absolute monocyte count; $\mathrm{ANC}=$ absolute neutrophil count; $\mathrm{WBC}=$ white $\mathrm{blood}$ cell count; $\mathrm{Hgb}=$ hemoglobin; Plts = platelets; LDH = lactate dehydrogenase; IPI = International Prognostic Index.

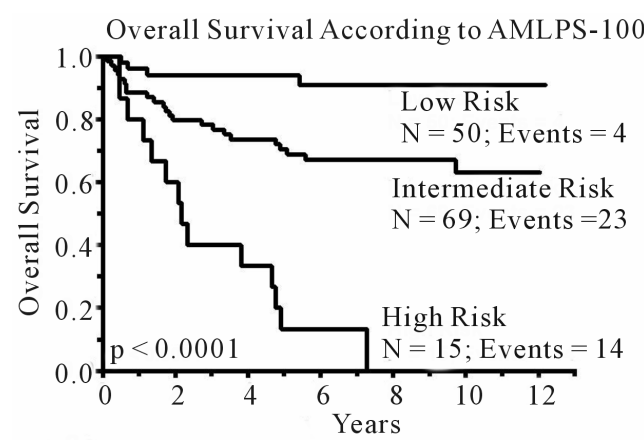

(a)

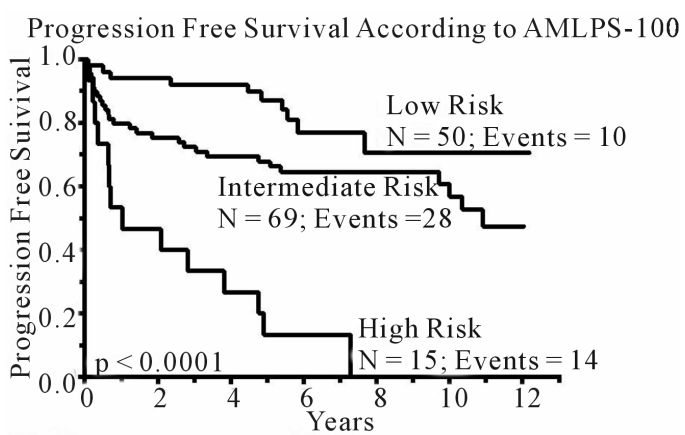

(b)

Figure 2. Kaplan-Meier estimates of overall (a) and progression free (b) survival for the entire cohort of patients stratified by the AMC/ALC prognostic score at day 100 (AMLPS-100, stratifying patients into low risk (ALC-100 $>1000$ cells/ $\mu \mathrm{L}$ and AMC-100 < 630 cells $/ \mu \mathrm{L}$ ); intermediate-risk (ALC-100 $\leq 1000$ cells $/ \mu \mathrm{L}$ or AMC-100 $\geq 630$ cells $/ \mu \mathrm{L}$ ); and high-risk (ALC-100 $\leq 1000$ cells $/ \mu \mathrm{L}$ and $\mathrm{AMC}-100 \geq 630$ cells $/ \mu \mathrm{L})$.

100 retains its ability to predict clinical outcomes at day 100 post-APBHSCT making it a risk-assessing tool that could be used during follow-up of DLBCL patients in complete remission.

To support the hypothesis that the biomarker AMLPS100 affects survival in DLBCL patients, it was necessary to demonstrate that both ALC-100 and AMC-100 were associated with clinical outcomes in DLBCL patients in complete remission at day 100 post-APBHSCT. We determined that DLBCL patients presenting with ALC-100 $>1000$ cells $/ \mu \mathrm{L}$ experienced significantly superior OS and PFS. Similarly, DLBCL patients with an AMC-100 $<630$ cells $/ \mu \mathrm{L}$ presented superior OS and PFS from day 100 post-APBHSCT. 
Since both the ALC-100 and AMC-100 were independent predictors for OS and PFS, we combined them into AMLPS-100. The AMLPS-100 was able to stratify patients into low-, intermediate-, and high-risk groups for OS and PFS post-APBHSCT.

To minimize the inherent biases of a retrospective study, the following steps were taken. With regards to selection bias, we only included DLBCL patients that underwent APBHSCT. Patients infused with peripheral blood as well as bone marrow harvested stem cells were excluded. All patients were treated with the same conditioning regimen. All patients were required to be in complete remission at day 100 for the landmark analysis. With regards to confounding factors, our study included currently known prognostic factors, such as the IPI; in addition, we included Age-100, Hgb-100, ANC-100, LDH100, WBC-100, and Plts-100, all of which have been reported as prognostic factors at day 100 post-allogeneic stem cell transplantation [1-4].

On the other hand, strengths of this study include the long follow-up period of a well-defined group of DLBCL patients in complete remission at day 100 postAPBHSCT, with a median follow-up from day 100 postAPBHSCT for the cohort of 5.5 years and 6.9 years for living patients. Secondly, AMLPS-100 combines clinical biomarkers for the host immunity (i.e., ALC) [5] and tumor microenvironment (i.e., AMC) [26,27]. Thirdly, the AMLPS-100 is a simple biomarker score obtained from the day $100 \mathrm{CBC}$ post-APBHSCT that can be used to assess clinical outcomes in DLBCL patients in complete remission at day 100 post-APBHSCT, whereas other prognostic techniques such as gene-expression profiling required fresh frozen tissue samples, limiting its use in complete remission DLBCL patients at day 100 post-APBHSCT. Further studies are warranted to validate the AMLPS- 100 .

\section{Acknowledgements}

This publication was supported in part by Mayo CTSA Grant Number UL1TR000135 from the National Center for Advancing Translational Sciences. Its contents are solely the responsibility of the authors and do not necessarily represent the official view of NIH.

\section{REFERENCES}

[1] L. J. DeCook, M. Thoma, T. Huneke, N. D. Johnson, R. A., M. M. Patnaik, et al., "Impact of Lymphocyte and Monocyte Recovery on the Outcomes of Allogeneic Hematopoietic SCT with Fludarabine and Melphalan Conditioning," Bone Marrow Transplantation, Vol. 48, No. 5, 2013, pp. 708-714.

http://dx.doi.org/10.1038/bmt.2012.211

[2] B. Bolwell, B. Pohlman, R. Sobecks, S. Andresen, S.
Brown, L. Rybicki, et al., " Prognostic Importance of the Platelet Count 100 Days Post Allogeneic Bone Marrow Transplant," Bone Marrow Transplantation, Vol. 33, No. 4, 2004, pp. 419-423.

http://dx.doi.org/10.1038/sj.bmt.1704330

[3] Z. Kuzmina, S. Eder, A Bohm, E. Pernicka, L. Vormittag, P. Kahs, et al., "Significant Worse Survival of Patients with NIH-Defined Chronic Graft-versus-Host Disease and Thrombocytopenia or Progressive Onset Type: Results of a Prospective Study," Leukemia, Vol. 26, No. 4, 2012, pp. 746-756.

http://dx.doi.org/10.1038/leu.2011.257

[4] S. G. Holtan, W. J. Hogan, M. A. Elliott, S. M. Ansell, D. J. Inwards, L. F. Porrata, et al., "CD34+ Cell Dose and Establishment of Full Donor Chimerism at Day +100 Are Important Factors for Survival with Reduced-Intensity Conditioning with Fludarabine and Melphalan before Allogeneic Hematopoietic SCT for Hematologic Malignancies," Bone Marrow Transplantation, Vol. 45, No. 12, 2010, pp. 1699-1703.

http://dx.doi.org/10.1038/bmt.2010.49

[5] R. A. Wilcox, K. Ristow, T. M. Habermann, D. J. Inwards, I. N. M. Micallef, P. B. Johnston, et al., "The Absolute Monocyte and Lymphocyte Prognostic Score Predicts Survival and Identifies High-Risk Patients in Diffuse Large-B-Cell Lymphoma," Leukemia, Vol. 25, No. 9, 2011, pp. 1502-1509.

http://dx.doi.org/10.1038/leu.2011.112

[6] N. Batty, E. Ghonimi, L. Feng, L. Fayad, A. Younes, M. A. Rodriguez, et al., "The Absolute Monocyte and Lymphocyte Prognostic Index for Patients with Diffuse LargeB-Cell Lymphoma Who Receive R-CHOP," Clinical Lymphoma, Myeloma \& Leukemia, Vol. 13, No. 1, 2013, pp. 15-18. http://dx.doi.org/10.1016/j.clml.2012.09.009

[7] C. Keane, D. Gill, F. Vari, D. Cross, L. Griffiths and M. Gandhi, "CD4 Tumor Infiltrating Lymphocytes Are Prognostic and Independent of R-IPI in Patients with DLBCL Receiving R-CHOP Chemo-Immunotherapy," American Journal of Hematology, Vol. 88, No. 4, 2013, pp. 273276. http://dx.doi.org/10.1002/ajh.23398

[8] D. K. Hiwase, S. Hiwase, M. Bailey, G. Bollard and A. P. Schwarer, "Higher Infused Lymphocyte Dose Predicts Higher Lymphocyte Recovery, Which in Turn, Predicts Superior Overall Survival Following Autologous Hematopoietic Stem Cell Transplantation for Multiple Myeloma," Biology of Blood and Marrow Transplantation, Vol. 14, No. 7, 2008, pp. 116-124. http://dx.doi.org/10.1016/j.bbmt.2007.08.051

[9] L. F. Porrata, D. J. Inwards, S. M. Ansell, I. N. Micallef, P. B. Johnston, D. A. Gastineau, et al., "Early Lymphocyte Recovery Predicts Superior Survival after Autologous Stem Cell Transplantation in Non-Hodgkin Lymphoma: A Prospective Study," Biology of Blood and Marrow Transplantation, Vol. 14, No. 7, 2008, pp. 807-816. http://dx.doi.org/10.1016/j.bbmt.2008.04.013

[10] D. G. Stover, V. K. Reddy, Y. Shyr, B. N. Savani and N. Reddy, "Long-Term Impact of Prior Rituximab Therapy and Early Lymphocyte Recovery on Auto-SCT Outcome for Diffuse Large B-Cell Lymphoma," Bone Marrow Tran- 
splantation, Vol. 47, No. 1, 2012, pp. 82-87.

http://dx.doi.org/10.1038/bmt.2011.29

[11] L. F. Porrata, M. A. Gertz, D. J. Inwards, M. R. Litzow, M. Q. Lacy, A. Tefferi, et al., "Early Lymphocyte Recovery Predicts Superior Survival after Autologous Hematopoietic Stem Cell Transplantation in Multiple Myeloma or Non-Hodgkin Lymphoma," Blood, Vol. 98, No. 3, 2001, pp. 579-585.

http://dx.doi.org/10.1182/blood.V98.3.579

[12] M. R. Boulassel, A. L. Herr, M. D. DebEdwards, A. Galal, S. Lachance, P. Laneuville, et al., "Early Lymphocyte Recovery Following Autologous Peripheral Stem Cell Transplantation Is Associated with Better Survival in Younger Patients with Lymphoproliferative Disorders," Hematology, Vol. 11, No. 3, 2006, pp. 165-170. http://dx.doi.org/10.1080/10245330600667559

[13] L. N. Gordan, M. W. Sugrue, J. W. Lynch, K. D. Williams, S. A. Khan and J. S. Moreb, "Correlation of Early Lymphocyte Recovery and Progression-Free Survival after Autologous Stem-Cell Transplant in Patients with Hodgkin's and Non-Hodgkin's Lymphoma," Bone Marrow Transplantation, Vol. 31, No. 11, 2003, pp. 10091013. http://dx.doi.org/10.1038/sj.bmt. 1704050

[14] C. Joao, L. F. Porrata, D. J. Inwards, S. M. Ansell, I. N. Micallef, P. B. Johnston, et al., "Early Lymphocyte Recovery after Autologous Stem Cell Transplantation Predicts Superior Survival in Mantle-Cell Lymphoma," Bone Marrow Transplantation, Vol. 37, No. 9, 2006, pp. 865871. http://dx.doi.org/10.1038/sj.bmt.1705342

[15] H. Kim, H. J. Sohn, S. Kim, J. S. Lee, W. K. Kim and C. Suh, "Early Lymphocyte Recovery Predicts Longer Survival after Autologous Peripheral Blood Stem Cell Transplantation in Multiple Myeloma," Bone Marrow Transplantation, Vol. 37, No. 11, 2006, pp. 1037-1042. http://dx.doi.org/10.1038/sj.bmt.1705373

[16] H. Kim, H. J. Sohn, S. E. Kim, H. J. Kang, S. Park, S. Kim, et al., "Lymphocyte Recovery Prolonged Survival after Autologous Peripheral Blood Stem Cell Transplantation in T-Cell Non-Hodgkin's Lymphoma," Bone Marrow Transplantation, Vol. 34, No. 1, 2004, pp. 43-49. http://dx.doi.org/10.1038/sj.bmt.1704530

[17] L. F. Porrata, M. A. Gertz, M. R. Litzow, M. Q Lacy, A. Dispenzieri, D. J. Inwards, et al., "Early Lymphocyte Recovery Predicts Superior Survival after Autologous Hematopoietic Stem Cell Transplantation for Patients with Primary Systemic Amyloidosis," Clinical Cancer Research, Vol. 11, 2005, pp. 1120-1218.

[18] L. F. Porrata, D. J. Inwards, I. N. Micallef, S. M. Ansell, S. M. Geyer and S. N. Markovic, "Early Lymphocyte Recovery Post-Autologous Haematopoietic Stem Cell Transplantation Is Associated with Better Survival in Hodgkin's Disease," British Journal of Haematology, Vol. 117,
No. 3, 2006, pp. 629-633.

http://dx.doi.org/10.1046/j.1365-2141.2002.03478.x

[19] L. F. Porrata, M. R. Litzow, A. Tefferi, L. Letendre, S. Kumar, S. M. Gever, et al., "Early Lymphocyte Recovery Is a Predictive Factor for Prolonged Survival after Autologous Hematopoietic Stem Cell Transplantation for Acute Myelogenous Leukemia," Leukemia, Vol. 16, No. 7, 2002, pp. 1311-1318. http://dx.doi.org/10.1038/sj.leu.2402503

[20] G. Ferrandina, L. Pierelli, A. Perillo, S. Rutela, M. Ludovisi, G. Leone, et al., "Lymphocyte Recovery in Advanced Ovarian Cancer Patients after High-Dose Chemotherapy and Peripheral Blood Stem Cell Plus Growth Factor Support: Clinical Implications," Clinical Cancer Research, Vol. 9, 2003, pp. 195-200.

[21] Y. Nieto, E. J. Shpall, I. K. McNiece, S. Nawaz, J. Beaudet, S. Rosinki, et al., "Prognostic Analysis Of Early Lymphocyte Recovery in Patients with Advanced Breast Cancer Receiving High-Dose Chemotherapy with an Autologous Hematopoietic Progenitor Cell Transplant," Clinical Cancer Research, Vol. 10, 2004, pp. 5076-5086.

[22] L. F. Porrata, J. N. Ingle, M. R. Litzow, S, Geyer and S. N. Markovic, "Prolonged Survival Associated with Early Lymphocyte Recovery after Autologous Hematopoietic Stem Cell Transplantation for Patients with Metastatic Breast Cancer," Bone Marrow Transplantation, Vol. 28, No. 9, 2001, pp. 865-871. http://dx.doi.org/10.1038/sj.bmt.1703236

[23] B. D. Cheson, B. Pfistner, M. E. Juweid, R. D. Gascoyne, L. Specht, S. J. Horning, et al., "Revised Response Criteria for Malignant Lymphoma," Journal of Clinical Oncology, Vol. 25, No. 5, 2007, pp. 579-586. http://dx.doi.org/10.1200/JCO.2006.09.2403

[24] E. L. Kaplan and P. Meier, "Nonparametric Estimation from Incomplete Observations," Journal of the American Statistical Association, Vol. 53, No. 282, 1958, pp. 457 481. http://dx.doi.org/10.1080/01621459.1958.10501452

[25] D. Cox, "Regression Models and Life Tables," Journal of the Royal Statistical Society B, Vol. 34, 1972, pp. 187202.

[26] C. M. Diaz-Montero, M. L. Salem, M. I. Nishimura, E. Garrett-Mayer, D. J. Cole and A. J. Montero, "Increased Circulating Myeloid-Derived Suppressor Cells Correlate with Clinical Cancer Stage, Metastatic Tumor Burden, and Doxorubicin-Cyclophosphamide Chemotherapy," Cancer Immunology, Immunotherapy: CII, Vol. 58, 2009, pp. 49-59.

[27] D. I. Gabrilovich and S. Nagaraj, "Myeloid-Derived Suppressor Cells as Regulators of the Immune System," $\mathrm{Na}$ ture Reviews Immunology, Vol. 9, 2009, pp. 162-174. 